\title{
TRANSESOPHAGEAL ECHOCARDIOGRAPHY DISCLOSES UNEXPECTED CARDIAC SOURCES OF EMBOLUS IN STROKE PATIENTS AGED MORE THAN 45 YEARS
}

\author{
Marcia Maiumi Fukujima', Solange Bernardes Tatani², \\ Alexandre Santos Aguiar', Maria Elisabeth Matta de Rezende Ferraz', \\ Silvio Francisco', Luiz Darcy Ferreira ${ }^{4}$, Cláudia G. Monaco ${ }^{4}$, Juarez Ortiz', \\ João Augusto Costa Lima5, Alberto Alain Gabbai', Gilmar Fernandes do Prado ${ }^{1}$
}

\begin{abstract}
Cerebral embolism from cardiac source is an important cause of stroke, specially in patients younger than 45 years old. Objective: To describe the transesophageal echocardiography (TEE) findings in young and non-young stroke patients without any prior evidence of cardiac source for cerebral embolism. Method: Transversal study: 523 patients (267 men and 256 women) with ischemic stroke, without any evidence of cardiac abnomality, underwent to TEE. Results: Ten percent were aged 45 years; or less. Left ventricle hypert rophy, left atrial enlargement, spontaneous contrast in aorta, interatrial septum aneurysm, mitral and aortic valve calcification, aortic valve regurgitation, and atherosclerotic plaques in aorta were significantly more frequent in patients aged more than 45 years; $2.8 \%$ of non-young patients had thro mbus in left heart. Conclusion: TEE is widely used to diagnose cardiac source of cerebral embolism in young patients, but it seems to be as useful for older ones, in whom cerebral embolism risk is underestimated; atherogenic and cardioembolic causes may actually coexist, and both should be treated.
\end{abstract}

KEY WORDS: stroke, cardiac embolism, transesophageal echocardiogram.

\section{Ecocardograma transesofágico revela fonte cardíaca de embolia cerebral em pacientes com AVC e mais que 45 anos}

\begin{abstract}
RESUMO - Embolia cerebral de fonte cardíaca é frequentemente relacionada a acidente vascular cerebral (AVC) em jovem. Objetivo: Descrever achados ecocardiográficos em jovens e não jovens com AVC isquêmico, sem suspeita de fonte cardíaca. Método: Estudo transversal; 523 pacientes (267 homens e 256 mulheres) com AVC isquêmico sem evidência de fonte cardíaca submeteram-se ao ecocardiograma transesofágico (ECOTE). Resultados: $10 \%$ dos pacientes tinha 45 anos; ou menos. Hipert rofia do ventrículo esquerdo, aumento do átrio esquerdo, contraste espontâneo na aorta, aneurisma do septo interatrial, calcificação da válvula mitral e aórtica, insuficiência aórtica e placas de ateroma na aorta foram significantemente mais frequentes nos pacientes com mais que 45 anos; $2.8 \%$ dos não-jovens apresentaram trombo nas câmaras esquerdas. Conclusão: ECOTE é amplamente sugerido na investigação de embolia em pacientes jovens, porém parece ser tão importante também no grupo de pacientes mais velhos, nos quais o risco de embolia cerebral é subestimado; etiologia cardioembólica e aterosclerótica coexistem, e ambas devem ser identificadas e tratadas para melhor prognóstico.
\end{abstract}

PALAVRAS-CHAVE: acidente vascular cerebral, embolia cardíaca, ecocardiograma transesofágico.

Ce rebral embolism from cardiac source (CECS) is considered the cause of 15 to $45 \%$ of all strokes, and many studies suggest that it is more prevalent in patients younger than 45 years old ${ }^{1-3}$. The absence of qualitatively valid criteria for the clinical diagnosis of CECS, and the frequent coexistence of a potential cardiac source of emboli and cerebral atherosclerosis, make the diagnosis presumptive in

\footnotetext{
${ }^{1}$ Neurologist, Division of Neurological Emergencies, São Paulo Federal University, São Paulo, Brazil (UNIFESP); ${ }^{2} \mathrm{C}$ a rdiologist, Division of Cardiology, UNIFESP; ${ }^{3} \mathrm{MD}$ Statistical consultant, São Paulo, Brazil; ${ }^{4} \mathrm{Ca}$ rdiologist, OMNI - Non-invasive Cardiological Diagnosis Center, São Paulo, Brasil; ${ }^{5} \mathrm{C}$ a rdiologist, Division of Card i o logy, Johns Hopkins University, Baltimore, USA. This study was support ed by Sigma Pharma.
}

Received 30 March 2005, received in final form 2 June 2005. Accepted 13 July 2005. 
many situations. There is neither consensus nor guidelines for diagnosis of CECS. About one third of all stroke patients have some clinical evidence of potential cardiac source of embolism by physical examination, chest roentgenogram or electrocardiogram ${ }^{2}$. The classical cardiac conditions associated with CECS are nonvalvular atrial fibrillation, acute myocardial infarction, ventricular aneurysm, rheumatic heart disease, and prosthetic valves, and some studies have correlated specific entities to less common potential cardiac source of cerebral embolism: mitral valve prolapse, mitral annulus calcification, nonbacterial thrombotic endocarditis, calcified aortic valve stenosis, myxoma, paradoxical e mbolism and congenital heart disease, nonischemic dilated cardiomyopathy, and infective endocarditis ${ }^{1}$. Aging produces major cardiovascular changes, including decreased elasticity and compliance of the aorta and other arteries, that leads to higher systolic arterial pressure and increased impedance to left ventricle ejection, and subsequent left ventricle hypertrophy. Heart valves thicken and calcification results at the basis of aortic valve and mitral annulus causing valve dysfunction. Aortic valve calcification is associated with atherosclercic disease, specially coronary artery disease. Various types of arrhythmia are associated with cell degeneration, and occur preferentially in the elderly ${ }^{4}$.

The transesophageal echocardiography (TEE) was first used in 1971, and has been very useful in the diagnosis of many cardiac abnormalities, some of them associated to unsuspected ethiology for stroke, as follows: patent foramen ovale, atrial communication, atrial septal aneurysm, aortic atheromatous plaques, echocardiographic spontaneous contrast, mitral valve strands, intracardiac thro mbus specially in left appendage $\mathrm{e}^{5-7}$. The TEE has been more widely used since the eighties when technical improvements mostly rega roing transducers, and topic anesthetic proced ures were achieved ${ }^{3,8}$. It is well known the superiority of TEE compared to transthoracic echocardiography to detect the abo-

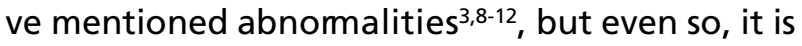
not widely used in the stroke investigation ${ }^{13}$.

Some algorithms for cardiac evaluation, until last decade, included TEE for young stroke patients, and for older only if there was some evidence of cardiac disease ${ }^{9,14-17}$. A recent guideline recommend echocardiography for young stroke patients and for older patients (typically more than 45 years) only with neurological events without evidence of cerebrovascular disease or other obvious cause ${ }^{18}$.
The objective of this study was to describe the TEE findings in young and non-young stroke patients without any prior evidence of cardiac source for cerebral embolism. Our hypothesis is that we are underestimating cerebral embolism risk in an older population and therefore it would be useful to submit every patient with acute stroke to TEE in order to diagnose unsuspected sources of embolism.

\section{METHOD}

Patients and design - Transversal study with consecutive inclusion of 523 adult patients between November 1998 and March 2004. Patients were admitted to the Division of Neurological Emergencies of São Paulo Hospital at Federal University of São Paulo, and were enrolled if they fulfilled the entry criteria, and signed the consent form. The diagnosis of ischemic stroke were performed by neurologists following a standard protocol including clinical examination and brain CT scan. The selected patients underwent TEE up to 15 days after stroke.

Exclusion criteria - Patients bearing any clinical suspicion of cardioembolism like atrial fibrillation, recent myocardial infarction (in the last 6 months), prosthetic ca rdiac valves, severe impairment of cardiac function, fo rmal contraindication for TEE, critical care required or those hospitalized for more than 14 days were excluded from the study.

Group assignment - Based on current criteria patients aged 45 or less were considered young, and those aged more than 45 years were considered non-young ${ }^{19}$. To analyze clinical data we split our sample into male and female groups because known epidemiological differences among them.

TEE - Multplane transesophageal echocardiography with a $5 \mathrm{mHz}$ transesophageal probe (Vingmed echocardiography System $V$ ) were performed to the selected patients. Images were recorded on videotape for later review by two observers. TEE examinations were performed after administration of topical anesthesia with an aerosolized $10 \%$ solution of lydocaine and intravenous sedation with midazolan $(1.5 \mathrm{mg} / \mathrm{ml})$ and meperidine $(50 \mathrm{mg} / \mathrm{ml})$. Contrast studies were performed through rapid injection of microbubble solution $(6 \mathrm{ml}$ of isotonic saline $0.9 \%, 4 \mathrm{ml}$ of glucosis $50 \%$, and $1 \mathrm{ml}$ of air) in the peripheral vein at rest, during coughing, and Valsalva maneuver. A comprehensive TEE examination was perf o rmed with standardized scan planes. The following abnormalities were evaluated: left atrium enlargement, presence of masses, thrombi, or spontaneous contrast either inside the atrium or at the atrial appendage or left ventricle, interatrial septum aneurysm; patent foramen ovale, or any interatrial septal communication; fibrosis, mitral valve strands, calcifications, myxomatous 
degeneration, significant stenosis, or regu rgitation of the mitral or aortic valve; enlargement, hypert rophy, left ventricle segmental or global dysfunction; and also atherosclerotic plaques or thrombi in the thoracic aorta. Patent foramen ovale was diagnosed if more than th ree microbubbles were detected in the left atrium within 5 cardiac cycles, following the opacification in the right atrium. Interatrial septal aneurysm was diagnosed when excessive expansion was observed. Spontaneous echo contrast was characterized by smooth echoes with ciraular or spiral movement inside cardiac chambers. Mitral valve strands were defined as a thin mobile filamentous projections attached to the atrial surface of mitral leaflets or subvalvar apparatus. The left atrium was considered enlarged when it was $>40 \mathrm{~mm}$. The left ventricle was considered enlarged when diastolic diameter was $>50 \mathrm{~mm}$ and hypert rophic when diastolic thickness was $\geq 12 \mathrm{~mm}$; athero scle rotic plaques in the ascending a orta, aortic arch, and descending aorta had their maximum thickness measured and were classified into 2 groups: those $<4 \mathrm{~mm}$ and those $\geq 4 \mathrm{~mm}$.

Statistical analysis - Proportions and $95 \%$ confidence intenal were computed for echocardiographic findings. Qui-squaretests were performed to compare the proportions of each group. A $p$ value $<0.05$ was considered significant. Calculations were performed with SPSS 12 (SPSS Inc., U.S.A.) statistical package.

The sponsor played no role in elaboration and conduction of this study.

\section{RESULTS}

There were 523 patients included in the study (267 men and 256 women); the ages ranged fro $m$ 26 to 92 years ( mean $=62.8 ; S D=12.47$ ). Fifty-four patients $(10.3 \%)$ were aged 45 years or less (23 man and 31 women) and 469 patients (89.7\%) were aged more than 45 years ( 244 men and 225 women).

No complications occurred during the echocardiography exam. One patient could not be submitted to TEE because of esophagitis diagnosed during the procedure.
The women of non-young group presented a higher proportion of hypertension and diabetes, and lower proportion of cigarette smoking. The men of non-young group had lower proportion of cigarette smoking (Table 1).

Left ventricle hypertrophy, left atrial enlarg ement, spontaneous contrast in aorta, interatrial septum aneurysm, mitral valve calcification, aortic valve calcification, aortic valve re $\mathrm{g}$ u rgitation, and atherosclerotic plaques in aorta were more frequent in patients aged more than 45 years. Echocardiographic findings are presented in Table 2. Neither mass in left atrium or ventricle nor strands in mitral valve were found.

Four patients had intermittent atrial fibrillation not present during emergency management, all of them were aged more than 45 years old. Four patients presented aortic aneurysms with signs of dissection (43 years old woman, 46 years old woman, 59 years old woman, and 58 years old man). In 1 patient of young group, who had aortic aneurysm dissection and also thrombus, and in 17 patients of non-young group (atrial fibrillation, aortic aneurysm dissection, mitral stenosis, aortic stenosis, or thrombus) the treatment change was mandatory, and was performed immediately after TEE.

Six TEE were considered normal (14.3\%) in the group of young patients, and $5(1.4 \%)$ amongst older patients $(p<0.0001)$.

\section{DISCUSSION}

The proportion of young patients with stroke in the present study $(10.8 \%)$ was similar to that previously reported in Brazil (10.6\% of cerebral infarct $)^{20}$, and in other countries ${ }^{21}$, showing that stroke is not rare in young people. Considering that cardioembolism is an important ethiology of stroke

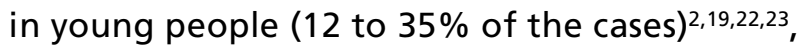
and that patients with any suspected cardiac source of embolism were excluded from our study, the

Table 1. Atherosclerotic risk factors of male and female stroke patients distributed by ages.

\begin{tabular}{lcccccc}
\hline & \multicolumn{3}{c}{ Women $(\mathrm{n}=256)$} & \multicolumn{3}{c}{ Men $(\mathrm{n}=267)$} \\
\cline { 2 - 7 } & $\begin{array}{c}\text { 45 years } \\
(\mathrm{n}=31)\end{array}$ & $\begin{array}{c}>45 \text { years } \\
(\mathrm{n}=225)\end{array}$ & $\mathrm{p}$ & $\begin{array}{c}\text { 45 years } \\
(\mathrm{n}=23)\end{array}$ & $\begin{array}{c}>45 \text { years } \\
(\mathrm{n}=224)\end{array}$ & $\mathrm{p}$ \\
\hline Hypertension & 18 & 192 & 0.0002 & 14 & 189 & 0.0748 \\
Diabetes mellitus & 4 & 69 & 0.0400 & 2 & 60 & 0.0844 \\
Previous stroke & 5 & 53 & 0.3544 & 5 & 60 & 0.7607 \\
Coronary disease & 2 & 26 & 0.3933 & 4 & 42 & 0.9827 \\
Cigarette smoking & 20 & 49 & $<0.0001$ & 16 & 107 & 0.0180 \\
\hline
\end{tabular}

Qui-square test. 
Table 2. Echocardiography findings in patients younger and older than 45 years.

\begin{tabular}{|c|c|c|c|c|c|c|c|}
\hline \multirow[b]{2}{*}{$\begin{array}{l}\text { Echocardiographic } \\
\text { findings }\end{array}$} & \multicolumn{3}{|c|}{$\leq 45$ years $(\mathrm{N}=54)$} & \multicolumn{3}{|c|}{$>45$ years $(\mathrm{N}=469)$} & \multirow[b]{2}{*}{$\mathrm{p}$} \\
\hline & $\mathrm{N}$ & proportion & $\begin{array}{l}95 \% \text { Confidence } \\
\text { interval }\end{array}$ & $\mathrm{N}$ & proportion & $\begin{array}{c}95 \% \text { Confidence } \\
\text { interval }\end{array}$ & \\
\hline Left ventricle hypertrophy & 8 & 0.1481 & $0.0662-0.2712$ & 200 & 0.4264 & $0.3812-0.4726$ & 0.0001 \\
\hline Left atrium enlargement & 3 & 0.0556 & $0.0116-0.1539$ & 128 & 0.2729 & $0.2331-0.3157$ & 0.0005 \\
\hline Left ventricle enlargement & 6 & 0.1111 & $0.0419-0.2263$ & 101 & 0.2154 & $0.1790-0.2554$ & 0.0721 \\
\hline $\begin{array}{l}\text { Spontaneous contrast } \\
\text { in left atrium }\end{array}$ & 4 & 0.0741 & $0.0206-0.1789$ & 77 & 0.1642 & $0.1318-0.2009$ & 0.0831 \\
\hline $\begin{array}{l}\text { Spontaneous contrast } \\
\text { in left ventricle }\end{array}$ & 0 & 0 & & 21 & 0.0448 & $0.0279-0.0676$ & 0.1125 \\
\hline $\begin{array}{l}\text { Spontaneous contrast } \\
\text { in aorta }\end{array}$ & 0 & 0 & & 45 & 0.0959 & $0.0708-0.1263$ & 0.0173 \\
\hline Thrombus in left atrium & 0 & 0 & & 5 & 0.0107 & $0.0035-0.0247$ & 0.4458 \\
\hline Thrombus in left ventricle & 0 & 0 & & 3 & 0.0064 & $0.0013-0.0186$ & 0.5556 \\
\hline Thrombus in aorta & 1 & 0.0185 & $0.0005-0.0989$ & 5 & 0.0107 & $0.0035-0.0247$ & 0.6076 \\
\hline Interatrial septum aneurysm & 0 & 0 & & 38 & 0.0810 & $0.0580-0.1095$ & 0.0298 \\
\hline Patent foramen ovale & 15 & 0.2778 & $0.1646-0.4164$ & 111 & 0.2367 & $0.1989-0.2778$ & 0.5036 \\
\hline Mitral valve calcification & 0 & 0 & & 91 & 0.1940 & $0.1592-0.2328$ & 0.0004 \\
\hline Aortic valve calcification & 1 & 0.0185 & $0.0005-0.0989$ & 155 & 0.3305 & $0.2880-0.3751$ & $<0.0001$ \\
\hline Mitral valve regurgitation & 34 & 0.6296 & $0.4874-0.7571$ & 349 & 0.7441 & $0.7021-0.7830$ & 0.0719 \\
\hline Aortic valve regurgitation & 7 & 0.1296 & $0.0537-0.2490$ & 193 & 0.4115 & $0.3666-0.4576$ & 0.0001 \\
\hline $\begin{array}{l}\text { Atherosclerotic plaque } \\
<4 \mathrm{~mm} \text { in aorta }\end{array}$ & 12 & 0.2222 & $0.1204-0.3560$ & 239 & 0.5096 & $0.4633-0.5557$ & 0.0001 \\
\hline $\begin{array}{l}\text { Atherosclerotic plaque } \\
>4 \mathrm{~mm} \text { in aorta }\end{array}$ & 2 & 0.0370 & $0.0045-0.1275$ & 125 & 0.2665 & $0.2270-0.3090$ & 0.0002 \\
\hline $\begin{array}{l}\text { Myxomatous valve } \\
\text { degeneration }\end{array}$ & 0 & 0 & & 4 & 0.0085 & $0.0023-0.0217$ & 0.4957 \\
\hline Mitral stenosis & 1 & 0.0185 & $0.0005-0.0989$ & 3 & 0.0064 & $0.0013-0.0186$ & 0.3329 \\
\hline OAortic stenosis & 0 & 0 & & 3 & 0.0064 & $0.0013-0.0186$ & 0.5556 \\
\hline
\end{tabular}

Qui-square test

actual proportion is likely to be even greater. Because of the low prevalence of atherosclesosis in the young, the cardiac conditions are more frequently related to the ethiology of stroke $2,21,24$.

Left ventricular hypertrophy, left atrial enlargement, left ventricle enlargement, spontaneous contrast in aorta, mitral valve calcification, aortic valve calcification, aortic valve regurgitation, and atherosclerotic plaques in aorta are related to aging, and were more prevalent in the older group as expected. PFO occurred in the older group in same proportion as younger group. PFO and atrial septal aneurysm are typically related to cryptogenic stroke ${ }^{25}$.

Atrial fibrillation and myocardial infarction are more prevalent in older patients, and are considered main sources of emboli'. However, in this study patients with some cardiac source of embolism were previously excluded, so the TEE findings were unexpected. Cabral et al. studied a similar population, without cardiac source of embolism, and found also more abnormalities in older group ${ }^{26}$. We have previously reported that $16 \%$ of patients had their treatments changed after TEE, leading to significant clinical impact ${ }^{27}$.

In current guideline for clinical application of echocardiography, it is recommended for younger patients, typically less than 45 years, with cere brovascular events and for older patients, typically more than 45 years, with neurological events without evidence of cere $b$ rovascular disease or other obvious cause. As aging is frequently related to obvious cause of ischemic stroke, considered athe- 
rothrombotic event, other etiologies are not systematically investigated ${ }^{14}$. Last Brazilian echocard i ography guideline also states as class I recommendation echocardiography for young patients $(<45$ years) with acute stroke, for patients older than 45 years without evidence of cerebrovascular disease, and for stroke with preexisting cerebrovascur lar disease with suspicion of embolus; also makes class II recommendations for echocardiography after acute neurological symptoms in patients with preexisting cere b rovascular disease, and for patients with stroke in whom echocardiography would not interfere in diagnosis or management ${ }^{28}$.

Clinical ${ }^{29}$, or review studies $9,17,30$ recommend echocardiography with the same restrictions of current guidelines, i.e., only for patients with stroke and atrial fibrillation, coron ary artery disease, and other cardiac diseases. Few studies recommend echocardography for patients without clinical suspicion of cardiac source of embolism 5 .

In our study we found in the group of non-young patients, 13 individuals (2.8\%) with some thro mbus, $6(1.3 \%)$ with mitral or aortic valve stenosis, $4(0.9 \%)$ with thoracic aorta dissection, $4(0.9 \%)$ with intermittent atrial fibrillation. Those patients demanded proper management, as well as some patients with other TEE abnormalities needed specific care. In the group of young patients 54 TEE were performed and we found one case of thrombus, while in the non-young group a change in management was mandatory at each 21 TEE.

TEE is widely used to diagnose cardiac source of cerebral embolism in young patients, but it seems to be as useful for older ones, in whom atherogenic and cardioembolic causes may actually coexist. In these patients the ethiological diagnosis of st roke is even more difficult, and it might be multifactorial. Each cause should be promptly identified and treated, reducing recurrence.

\section{REFERENCES}

1. Cerebral Embolism Task Force. Cardiogenic brain embolism. Arch Neurol 1986;43:71-84.

2. Ce rebral Embolism Task Force. Cardiogenic brain embolism: the second report of the Cerebral Embolism Task Force. Arch Neurol 1989; 46:727-743.

3. Hinchey JA, Furlan AJ, Barnett HJM. Cardiogenic brain embolism: incidence, varieties, and treatment. In Barnett HJM, Mohr JP, Stein BM, Yatsu FM (EDS). Stroke: pathophysiology, diagnosis, and management, 3rd edition. New York: Churchill Livingstone, 1998:1089-1119.

4. Cheitlin MD, Zipes DP. Cardiovascular disease in the elderly. In Braunwald E, Zipes DP, Libby P. (EDS) Heart disease: a textbook of card iovascular medicine, $6^{\text {th }}$ edition. Philadelphia: WB Saunders Company, 2001:2019-2037.

5. O'Brien PJ, Thiemann DR, McNamara RL, et al. Usefulness of transesophageal echocardiography in predicting mortality and morbidity in stroke patients without clinically known cardiac sources of embolus. Am J Cardiol 1998;81:1144-1151.

6. Mendel T, Pasierski T, Szwed H, Baranska-Gieruszczak M, Czlonbowska A. Transesophageal echocardiographic findings in patients with anterior and posterior circulation infarcts. Acta Neurol Scand 1998;97:63-67.

7. Bogousslavsky J, Cachin C, Regli F. Cardiac sources of embolism and cerebral infarction - clinical consequences and vascular concomitants: The Lausanne Stroke Registry. Neurology 1991;41:855-859.

8. Cujec B, Polasek P, Voel C, Shuaib A. Transesophageal echocardiography in the detection of potential cardiac source of embolism in stroke patients. Stroke 1991;22:727-733.

9. Lindower PD, Gutterman DD. Detection of cardioembolic sources with echocardiography. Comprehensive Therapy 1994;20:174-180.

10. Pearson AC, Labovitz AJ, Tatineni S, Gomez CR. Superiority of transesophageal echocardiography in detecting cardiac source of embolism in patients with cerebral ischemia of uncertain etiology. J Am Coll Cardiol 1991;17:66-72.

11. Armstrong WF, Feigenbaum H. Echocardiography. In Braunwald E, Zipes DP, Libby P (EDS). Heart disease: a textbook of cardiovascular medicine, $6^{\text {th }}$ edition. Philadelphia: WB Saunders Company, 2001:160-236.

12. McNamara RL, Lima JAC, Whelton PK, Powe NR. Echocardiographic identification of cardiovascular sources of emboli to guide clinical management of stroke: a cost-effectiveness analysis. Ann Intern Med 1997; 127:775-787.

13. Warner MF, Monah KI. Routine transesophageal echocardiography for cerebral ischemia: is it really necessary? Arch Intern Med 1996;156:1719-1723.

14. ACC/AHA guidelines for the clinical application of echocardiography. A report of the American College of Cardiology / American Heart Association Task Force on Assessment of Diagnostic and Therapeutic Cardiovascular Proced ures (Subcommittee to Develop Guidelines for the Clinical Application of Echocardiography) Circulation 1990;82:2323-2345.

15. DeRook FA, Comess KA, Albers GW, Popp RL. Transesophageal echocardiography in the evaluation of stroke. Ann Intern Med 1992;117:922-932.

16. Leung DY, Black IW, Cranney GB, et al. Selection of patients for transesophageal echocardiography after stroke and systemic embolic events: role of transthoracic echocardiography. Stroke 1995;26:1820-1824.

17. Husain AM, Alter M. Transesophageal echocardiography in diagnosing cardioembolic stroke. Clin Cardiol 1995;18:705-708.

18. Cheitlin MD, Armstrong WF, Aurigemma GP, et al. ACC/AHA/ASE 2003 guideline update for the clinical application of echocardiography: a report of the American College of Cardiology/American Heart A ssociation Task Force on Practice Guidelines (ACC/AHA/ASE Committee to update the 1997 Guideline for the Clinical application of Echocardiography). Circulation 2003;108:1278-1290.

19. Blecic S, Bogousslavski J. Stroke in young adults. In Barnett HJM, Mohr JP, Stein BM, Yatsu FM (EDS). Stroke: pathophysiology, diagnosis, and management. 3rd edition. New York: Churchill Livingstone, 1998:1001-1012.

20. Siqueira JI Neto, Santos JC, Fabio SC, Sakamoto A. Cerebral infarction in patients aged 15 to 40 years. Stroke 1996;27:2016-2019.

21. Bogousslavsky J, Pierre P. Ischemic stroke in patients under age 45. Neurol Clin 1992;10:113-124.

22. Adams HP Jr, Butler MJ, Biller J, Toffol GJ. Nonhemorrhagic cerebral infarction in young adults. Arch Neurol 1986;43:793-796.

23. Biller J, Johnson MR, Adams HP Jr, Kerber RE, To ffol GJ, Butler MJ. Echocardiographic evaluation of young adults with nonhemorrhagic cerebral infarction. Stroke 1986;17:608-612.

24. Olsen TS, Skriver EB, Herning M. Cause of cerebral infarction in the carotid territory: its relation to the size and the location of the infarct and to the underlying vascular lesion. Stroke 1985;16:459-466.

25. Cabanes L, Mas JL, Cohen A, et al. Atrial septal aneurysm and patent foramen ovale as risk factors for cryptogenic stroke in patients less than 55 years of age. Stroke 1993;24:1865-1873.

26. Cabral S, Oliveira F, Pereira S, et al. Transesophageal echocardiography in the assessment of patients presenting with ischemic cerebral events without previous evidence of a cardiac source of emboli. Rev Port Cardiol 2001;20:247-258.

27. Tatani SB, Fukujima MM, Lima JAC, et al. Clinical impact of transesophageal echocardiography in patients with stroke without clinical evidence of cardiovascular sources of emboli. A rq Bras Cardiol 2001; 76:453-461

28. Campos $\mathrm{O} \mathrm{F}^{\circ}$, Zielinsky P, Ortiz J. Diretriz para indicações e utilizações da ecocardiografia na prática clínica. A rqBras Cardiol 2004;82(Supl II): S11-S34.

29. Labovitz AJ, for the STEPS Investigators St. Louis, Mo. Transesophageal echocardiography and unexplained cerebral ischemia: a multicenter follow-up study. Am Heart J 1999;137:1082-1087.

30. Autore C, Cartoni D, Piccininno M. Multiplane transesophageal echocardiography and stroke. Am J Cardiol 1998;81:79G-81G. 